\title{
Evaluate the Relative Suitability of Commonly Used Adsorption Equation in Explaining the P Adsorption Behaviour of Inceptisol, Alfisol and Vertisol
}

\author{
Lalit Kumar Yadav, Gourav Kumar Jatav* and Rakesh Kumar Bhagat
}

Soil Science and Agricultural Chemistry, Indira Gandhi Krishi Vishwavidhyalaya, Raipur-492012, Chhattisgarh, India

*Corresponding author

\begin{tabular}{|c|c|}
\hline & A B S T R A C T \\
\hline & \multirow{6}{*}{$\begin{array}{l}\text { Soil Samples are collected for Phosphorus Adsorption behavior from three } \\
\text { representative soils of Chhattisgarh which belong to the Inceptisol, Alfisol and } \\
\text { Vertisol. Two adsorption equation viz., Langmuir and Freundlich were used to } \\
\text { describe P adsorption behavior. The P adsorption at the solid phase was strongly } \\
\text { related to its concentration in the solution phase and Vertisol with maximum clay } \\
\text { content recorded highest } \mathrm{P} \text { adsorption at a given equilibrium } \mathrm{P} \text { concentration } \\
\text { indicating that } \mathrm{P} \text { ions are most tightly held by Vertisol. The identical and high } \\
\text { values of } \mathrm{R}^{2} \text { both for Langmuir and Freundlich Adsorption Isotherms indicated } \\
\text { that the } \mathrm{P} \text { adsorption data conformed to both isotherms indicating their goodness } \\
\text { of fit. The P adsorption maxima ' } \mathrm{b} \text { ' was highest for Vertisol followed by Alfisol } \\
\text { and Incptisol. The value of Langmuir ' } \mathrm{K} \text { ' showed an increasing trend in the same } \\
\text { order indicating a high affinity of Vertisol for P, which had resulted in higher } \\
\text { value of 'b'. The value of Freundlich ' } \mathrm{n} \text { ' showed a slight increasing trend in the } \\
\text { order Vertisol > Alfisol > Inceptisol, whereas, its ' } \mathrm{K} \text { ' value showed a decreasing } \\
\text { trend in the same order. }\end{array}$} \\
\hline Keywords & \\
\hline $\begin{array}{l}\text { Soil, Relative } \\
\text { suitability, } \\
\text { Inceptisol, Alfi }\end{array}$ & \\
\hline Article & \\
\hline 10 Aug & \\
\hline & \\
\hline
\end{tabular}

\section{Introduction}

An adsorption equation is a mathematical The $\mathrm{P}$ adsorption at the solid phase was strongly related to its concentration in the solution phase and Vertisol with maximum clay content recorded highest $\mathrm{P}$ adsorption at a given equilibrium $\mathrm{P}$ concentration indicating that $\mathrm{P}$ ions are most tightly held by Vertisol.

The identical and high values of $\mathrm{R}^{2}$ both for Langmuir and Freundlich Adsorption Isotherms indicated that the $\mathrm{P}$ adsorption data conformed to both isotherms indicating their goodness of fit.
The $\mathrm{P}$ adsorption maxima ' $\mathrm{b}$ ' was highest for Vertisol followed by Alfisol and Incptisol. The value of Langmuir ' $K$ ' showed an increasing trend in the same order indicating a high affinity of Vertisol for $\mathrm{P}$, which had resulted in higher value of ' $b$ '. The value of Freundlich ' $\mathrm{n}$ ' showed a slight increasing trend in the order Vertisol > Alfisol > Inceptisol, whereas, its ' $\mathrm{K}$ ' value showed a decreasing trend in the same order. Expression which conveniently and quantitatively describes solute adsorption by solids at a constant temperature and an 
adsorption isotherm is graphical representation of adsorption equation which shows the amount of adsorbate sorbed (q) as a function of its equilibrium concentration (c). All the equations developed are based on the fundamental relation:

$\mathrm{Q}=\mathrm{F}(\mathrm{C})$.

The adsorption data is generated using a simple technique. A known amount of adsorbate is added to a system containing known amount of adsorbent. The amount of adsorbate removed from solution at equilibrium is assumed to be adsorbed.

The requirement for such studies is that equilibrium conditions must prevail and secondary reactions must be eliminated or corrected for. The most commonly used equations are that of Langmuir and Freundlich.

A common way to measure $\mathrm{P}$ sorption capacity in a soil is by construction of a sorption isotherm, which is the same as the soil Q/I plot. Phosphorus (P) adsorption isotherm integrates intensity, capacity and quantity parameters of $\mathrm{P}$ in soil and these factors play key role in controlling $\mathrm{P}$ flux to the root of growing plants (Kumar and Singh,1998). The adsorption isotherm has the advantage over the conventional method of soil testing as it predicts the quantity of $\mathrm{P}$ required by integrating the intensity, capacity and quantity parameters of $\mathrm{P}$ in soil, which play key role in controlling $\mathrm{P}$ flux to the root of growing plants (Mondal et al., 2004)

Equations such as the Langmuir, Freundlich and Tempkin models have been used to describe the relationship between the amount of $\mathrm{P}$ adsorbed to the $\mathrm{P}$ in solution at equilibrium (Berkheiser et al., 1980; Nair et al., 1984). The sorption maximum derived from the Langmuir equation is useful for estimating $\mathrm{P}$ sorption capacity and for comparing different soils. An advantage of using Langmuir equation is that it defines a limit to adsorption on a given array of sites. Adsorption of $\mathrm{P}$ by soils from the dilute solution has shown closer agreement with the Langmuir Isotherms than several other Isotherms. Therefore, this equation has been used by several investigators to estimate the adsorption capacity of soils as well as adsorption behavior (Thompson et al., 1960; Das et al., 1983; Vig and Dev, 1984; Ksishna Kumari et al., 1985.).

\section{Materials and Methods}

A Laboratory study was undertaking to investigate the $\mathrm{P}$ adsorption behavior of three representative soil of Chhattisgarh belonging to the order Inceptisol, Alfisol and Vertisol. Four Soil surface $(0-15 \mathrm{~cm})$ bulk soil samples each from different sites belonging to three soil orders - Inceptisol, Alfisol and Vertisol were collected from the experimental farm so as to have large variation in their properties. The sample were air dried, ground and passed through $2 \mathrm{~mm}$ sieve and used for adsorption studies in accordance with the method described by Fox and Kamprath (1970).

\section{Phosphorus adsorption study}

Data for plotting $\mathrm{P}$ adsorption isotherms were obtained by equilibrating $5 \mathrm{~g}$ soil in triplicate for 24 hours at $25^{\circ} \mathrm{C}$ in $50 \mathrm{ml} \mathrm{CaCl}_{2}$ solution containing varying amounts of $\mathrm{P}(0,30,60$, 90, 120, 150, 180, 210, 240, 270 and 300 ppm) as $\mathrm{KH}_{2} \mathrm{PO}_{4}$. Equilibration was carried out in $50 \mathrm{ml}$ centrifuge tubes by shaking for 24 hours. After shaking, the samples were centrifuged at $2500 \mathrm{rpm}$ for 10 minutes and then the concentration of $\mathrm{P}$ in the clear solution was determined by ascorbic acid method using Double Beam Spectrophotometer. The P which disappeared from the solution was considered to be 
adsorbed and calculated as:

Amount of $\mathrm{P}$ adsorbed in $\mu \mathrm{g} \mathrm{g}^{-1}(\mathrm{x} / \mathrm{m})=$ Initial conc. of the equilibrium solution -final concentration of the equilibrium solution in ppm (C).

\section{Preparation of $\mathbf{P}$ adsorption isotherms}

Two adsorption equations were fitted to the adsorption data obtained at different concentrations of added $\mathrm{P}$ as per the procedure of Fox and Kamprath, (1970).

\section{Langmuir adsorption isotherm}

The linear from of the Langmuir equation is:

$\frac{c}{\frac{x}{m}}=\frac{1}{K b}+\frac{c}{b}$

Where,

$\mathrm{C}=$ Equilibrium concentration of $\mathrm{P}(\mathrm{ppm})$

$\mathrm{x} / \mathrm{m}=$ Amount of $\mathrm{P}$ adsorbed per gram of soil $\left(\mu \mathrm{g} \mathrm{g}^{-1}\right)$

$\mathrm{b}=$ Adsorption maxima

$\mathrm{K}=$ Constant related to the binding energy

\section{Adsorption parameters}

P Adsorption maxima (b): A graph (scatter diagram) was plotted taking $\mathrm{C} /(\mathrm{x} / \mathrm{m})$ on $\mathrm{Y}$ axis and $\mathrm{C}$ on $\mathrm{X}$-axis and a straight line equation was fitted to the data to obtain the values of slope $(1 / \mathrm{b})$ and intercept $(1 / \mathrm{Kb})$.

The parameter ' $b$ ' was calculation as:

$b=\frac{1}{\operatorname{Slope}\left(\frac{1}{b}\right)}$

P bonding energy $(\mathrm{K})$ : The parameter ' $\mathrm{K}$ ' was calculated as:

$$
K=\frac{\text { Slope }\left(\frac{1}{b}\right)}{\text { Intercept }\left(\frac{1}{K b}\right)}
$$

\section{Freundlich adsorption isotherm}

The linear from of the freundlich equation is:

$\log \frac{x}{m}=\log K+\frac{1}{n} \log C$

Where,

$\mathrm{C}=$ Equilibrium concentration of $\mathrm{P}(\mathrm{ppm})$

$\mathrm{x} / \mathrm{m}=$ Amount of $\mathrm{P}$ adsorbed per gram of soil (ug g $\left.{ }^{-1}\right)$

$\mathrm{n}=$ empirical constant

$\mathrm{K}=$ empirical constant

\section{Adsorption parameters}

'n' : A graph (scatter diagram) was plotted taking $\log (\mathrm{x} / \mathrm{m})$ on $\mathrm{Y}$-axis and $\log \mathrm{C}$ on $\mathrm{X}$ axis and a straight line equation was fitted to the data to obtain the values of slope $(1 / n)$ and intercept $(\log K)$. The parameter ' $n$ ' was calculated as:

$n=\frac{1}{\text { Slope }\left(\frac{1}{n}\right)}$

' $\mathrm{K}$ ': The parameter ' $\mathrm{K}$ ' was calculated as:

$\mathrm{K}=$ Antilog Intercept $(\log \mathrm{K})$

\section{Results and Discussion}

The $\mathrm{P}$ adsorption study was conducted on three soils namely Inceptisol, Alfisol and Vertisol. The adsorption data obtained were fitted to Langmuir and Freundlich equations 
and adsorption were plotted for both the equations. The adsorption parameters pertaining to these equations were computed from these isotherms.

\section{Langmuir adsorption}

The Langmuir Adsorption Isotherm along with the Adsorption equation and value of $\mathrm{R}^{2}$ are presented in Table -1 .

The highly significant value of $\mathrm{R}^{2}$ indicated that the data fitted well to Langmuir equation for all the three soils which corroborated with the earlier finding of Singh and Singhpurei, (1986). The isotherms were liner even at the highest amount of added $\mathrm{P}$ in all the soils.
This perhaps indicated that in these soils, the $P$ adsorption sites were open.

The adsorption maxima ' $b$ ' and binding energy ' $\mathrm{K}$ ' were calculated from the slope and intercept of the Langmuir equation respectively, both of which are presented in Table - 1. It is evident from the table that the $P$ adsorption maxima ' $b$ ' was highest for Vertisol followed by Alfisol and Inceptisol. In values of $\mathrm{P}$ adsorption maxima varied in accordance with the clay content of the soils as also reported earlier by Toor et al., (1997). The binding energy ' $\mathrm{K}$ ' were almost similar and did not show any definite trend for individual samples of each soil group.

Table.1 Langmuir equation and Adsorption parameters for $\mathrm{P}$

\begin{tabular}{|c|c|c|c|c|}
\hline \multirow[t]{2}{*}{ Soil } & \multirow{2}{*}{$\begin{array}{c}(1 / \mathbf{K b}) \\
\text { Intercept }\end{array}$} & \multirow{2}{*}{$\begin{array}{c}(1 / b) \\
\text { Slope }\end{array}$} & \multicolumn{2}{|c|}{ Adsorption Parameters } \\
\hline & & & $\mathbf{b}^{\prime}\left(\mu g g^{-1}\right)$ & ' $\mathrm{K}^{\prime}\left(\mathrm{mL} \mu \mathrm{g}^{-1}\right)$ \\
\hline \multicolumn{5}{|c|}{ Inceptisol } \\
\hline $\mathbf{A}$ & 0.98781 & 0.00924 & 108.22511 & 0.00935 \\
\hline B & 0.39353 & 0.01296 & 77.16049 & 0.03293 \\
\hline $\mathbf{C}$ & 0.19054 & 0.01368 & 73.09942 & 0.07180 \\
\hline D & 0.60787 & 0.00994 & 100.60362 & 0.01635 \\
\hline \multicolumn{5}{|c|}{ Alfisol } \\
\hline $\mathbf{A}$ & 0.21479 & 0.00483 & 207.03934 & 0.02249 \\
\hline B & 0.31609 & 0.00571 & 175.13135 & 0.04196 \\
\hline $\mathbf{C}$ & 0.15859 & 0.00519 & 192.67823 & 0.03273 \\
\hline D & 0.18593 & 0.00595 & 168.06723 & 0.03200 \\
\hline \multicolumn{5}{|c|}{ Vertisol } \\
\hline $\mathbf{A}$ & 0.07417 & 0.00369 & 271.00271 & 0.04975 \\
\hline B & 0.05225 & 0.00472 & 211.86441 & 0.09033 \\
\hline $\mathbf{C}$ & 0.08093 & 0.00337 & 296.73591 & 0.04164 \\
\hline D & 0.12604 & 0.00435 & 229.88506 & 0.03451 \\
\hline
\end{tabular}

$1 / \mathrm{b}=$ Slope, $1 / \mathrm{Kb}=$ Intercept, $\mathrm{b}=$ Adsorption maxima $\left(\mu \mathrm{g} \mathrm{g}^{-1}\right), \mathrm{K}=$ Binding energy $\left({\left.\mathrm{mL} \mu \mathrm{g}^{-1}\right)}^{-1}\right.$ 
Table.2 Freundlich equation and Adsorption parameters for $\mathrm{P}$

\begin{tabular}{|c|c|c|c|c|}
\hline \multirow[t]{2}{*}{ Soil } & \multirow{2}{*}{$\begin{array}{c}\log K) \\
\text { Intercept }\end{array}$} & \multirow{2}{*}{$\begin{array}{l}(1 / \mathbf{n}) \\
\text { Slope }\end{array}$} & \multicolumn{2}{|c|}{ Adsorption Parameters } \\
\hline & & & 'n' & ' $\mathbf{K}$ ' \\
\hline \multicolumn{5}{|c|}{ Inceptisol } \\
\hline A & 0.50047 & 0.59496 & 1.68079 & 3.16570 \\
\hline B & 1.02305 & 0.36018 & 2.77639 & 10.54508 \\
\hline $\mathbf{C}$ & 1.24946 & 0.26720 & 3.74251 & 17.76070 \\
\hline D & 0.78578 & 0.49004 & 2.04065 & 6.10633 \\
\hline \multicolumn{5}{|c|}{ Alfisol } \\
\hline $\mathbf{A}$ & 1.11949 & 0.51719 & 1.93353 & 13.16710 \\
\hline B & 1.27468 & 0.44284 & 2.25815 & 18.82262 \\
\hline C & 1.17796 & 0.50413 & 1.98362 & 15.06468 \\
\hline D & 1.18403 & 0.46021 & 2.17292 & 15.27672 \\
\hline \multicolumn{5}{|c|}{ Vertisol } \\
\hline $\mathbf{A}$ & 1.35939 & 0.54962 & 1.81944 & 22.87652 \\
\hline B & 1.51502 & 0.41808 & 2.39189 & 32.73558 \\
\hline $\mathrm{C}$ & 1.30623 & 0.59372 & 1.68430 & 20.24091 \\
\hline D & 1.27034 & 0.50488 & 1.98067 & 18.63545 \\
\hline
\end{tabular}

$\log \mathrm{K}=$ Intercept, $1 / \mathrm{n}=$ Slope, $\mathrm{n} \& \mathrm{~K}=$ empirical constants

Table.3 Adsorption parameters averaged over four samples

\begin{tabular}{|l|c|c|c|c|c|c|c|c|}
\hline \multirow{2}{*}{ Soils } & \multicolumn{4}{|c|}{ Langmuir } & \multicolumn{4}{c|}{ Freundlich } \\
\cline { 2 - 9 } & $\mathbf{I}$ & $\mathbf{S}$ & $\mathbf{b}$ & $\mathbf{K}$ & $\mathbf{I}$ & $\mathbf{S}$ & $\mathbf{n}$ & $\mathbf{K}$ \\
\hline Inceptisol & 0.5435 & 0.0115 & 86.8056 & 0.0212 & 1.3654 & 0.5140 & 1.9455 & 23.1926 \\
\hline Alfisol & 0.1750 & 0.0054 & 184.5019 & 0.0310 & 1.1869 & 0.4825 & 2.0724 & 15.3769 \\
\hline Vertisol & 0.8498 & 0.0041 & 245.0980 & 0.0480 & 0.9219 & 0.4134 & 2.4188 & 8.3531 \\
\hline
\end{tabular}

I = Intercept, S = Slope

\section{Freundlich adsorption}

The Freundlich Adsorption Isotherms along with the equation and value of $\mathrm{R}^{2}$ are presented from Table -2 . The highly significant value of $\mathrm{R}^{2}$ obtained For Freundlich equation indicated that the data also fitted well to Freundlich equation for all the three soils. The value of ' $n$ ' and ' $K$ ' were calculated from the slope and intercept respectively and both are presented in Table 2. The ' $n$ ' value were almost similar and did not show any trend whereas the value of ' $\mathrm{K}$ ' seemed to be low for higher values of ' $K$ ' and vice versa.

Since the soils within the same group did not differ appreciably in respect of $\mathrm{P}$ adsorption parameters, probably owing to their similar mineralogical make-up, the data were averaged over all the four samples for each soil and the amount of $\mathrm{P}$ adsorbed $(\mathrm{x} / \mathrm{m})$ was plotted against the equilibrium $P$ concentration and is presented in Table -2 . The Table shows that a given equilibrium $P$ concentration, highest $\mathrm{P}$ was adsorbed by Vertisol and lowest by Inceptisol.

The data revealed that $\mathrm{P}$ adsorption maxima ' $b$ ' was highest for Vertisol and lowest for Inceptisol while Alfisol showed an intermediate value. The value of ' $\mathrm{K}$ ' showed an increasing trend in the same order indicating a high affinity of Vartisol for $\mathrm{P}$ which had resulted in higher value of ' $b$ '. Many workers have reported higher values of 
$\mathrm{K}$ and $\mathrm{b}$ Vertisols than other soils studies (Krishna Kumari et al., 1985; Kundu etal., 1988 and patil et al., 2000). The higher values of $\mathrm{P}$ adsorption maxima in Vertisols clearly indicate that these soils would require heavy doses of $\mathrm{P}$ for crop production. The variation in binding energy coefficient ' $K$ ' showed that besides higher amount adsorbed, $\mathrm{P}$ is also held with higher tenacity in soil having higher clay content. Thus, the release of $\mathrm{P}$ can be expected to be low in these soils having higher binding energy coefficient, since according to Holford and Mattingly (1976) the higher the bonding energy on the surface, more sorbed $\mathrm{P}$ is converted to unavailable form. Similarly, Freundlich Isotherms was also preapared based on the average of four soil sample for each soil type andis Presented in Table - 3. The adsorption parameter ' $n$ ' and ' $\mathrm{k}$ ' averaged over four soil sample from each soil type were computed and are presented in Table -3 . The value of ' $n$ ' showed a slight increasing trend in the order Vertisol > Alfisol $>$ Inceptisol, whereas, the value of ' $\mathrm{K}$ ' showed a decreasing trend in the same order.

\section{References}

Fox, R.L. and Kamprath, E.J. 1970. Phosphate Sorption Isotherms for evaluating the phosphate requirement of soils. Soil Science of America Proceeding.34:902-906.

Hartar, R. D.1969. Phosphateurn, adsorption sites in soils. Soil Sci. Soc. Am. Proc. 33:630-632.

Holford, I.C.R., Wedderburn, R.W.M. and Mattingly, G.E.G.1974.A Langmuir twosurface equation as a model for phosphate adsorption by soils. J. Soil Sci. 25:242-255.

Jalali, V.K. 1983. Studies on Phosphate adsorption in relation to phosphate needs of soils and crops in the soils of wet temperate Zone of H.P. Ph.D. Thesis. HPKVV, palmpur H.P. Jammu region Ph.D. Thesis, Division of Soil Science and Agricultural Chemistry KUASTJammu.

Jalali, V.K. and Shrama P.K. 1987.Phosphorous adsorption characteristics of some Himalayan soils. Proceedings of the National Symposium on Macronutrients in Soils and Crops held at PAU Ludhiana Dec.21-23, 1987.

Kanabo, I.A.K., Halm, A.J. and Obeng, H.B.1978. Phosphate adsorption by surface samples of five iron pan soils of Ghana. Geoderma.20:299-306.

Krishna Kumari, G., Adinarayana, V. Subba Rao, A. and Pillai, R.N.1985. Phosphate adsorption in some representative soils of Andhra Pradesh. J. Indian Soc. Soil Sci.33:666-668.

Krishna, G.T. and Sattyanaryana, T. 1995. Sorption of Phosphate as related to properties of Vertisols of northern Karnataka. Indian Soc. Soil Sci.441:153-155.

Kurtz, L.T., Deturk, E.E. and Bray, R.H. 1946. Phosphate adsorption by Illinois soils. Soil Science.61:111-125.

Manikandan, P. and Sastry, T G. 1988. Role of different soil components in Phosphate adsorption in some soils of Mysore plateau. J. Indian Soc. Soil Sci. 362:228-234.

Murthy, I.Y.L.N., Sastry, T.G., Datta, SC., Nrayanaswamy, G. and Rattan, R.K. 1996. Phosphorus Adsorption in relation to Soil Characteristics of vertisols Derived from Different Paranr Material. J. Indian Soc. Soil Sci. 23(3):319-327.

Nair, P.S. Logan, T.J., Sharpley, A.N., Sommers, L.E., Tabatabai, M. A. and Yuan, T.L.1984. Inter laboratory comparison of a standardized Phosphours adsorption procedure. Journal of Environmental Quality.13:591-595.

Sahrawat, K.L. and Warren, G.P. 1989. Sorption of labeled phosphate by a Vertisol and an Alfisol of the semiarid zone of India. Fertilizer Research.20:17-25.

\section{How to cite this article:}

Lalit Kumar Yadav, Gourav Kumar Jatav and Rakesh Kumar Bhagat. 2017. Evaluate the Relative Suitability of Commonly Used Adsorption Equation in Explaining the P Adsorption Behaviour of Inceptisol, Alfisol and Vertisol. Int.J.Curr.Microbiol.App.Sci. 6(8): 2816-2821. doi: https://doi.org/10.20546/ijcmas.2017.608.335 